\title{
Etika u arheologiji - od arheološkog iskopavanja do muzejskog izloška
}

Gabrić, Petar; Jelenić, Vera

Source / Izvornik: Filozofija i znanost, 2014, 179 - 193

Conference paper / Rad u zborniku

Publication status / Verzija rada: Published version / Objavljena verzija rada (izdavačev PDF)

Permanent link / Trajna poveznica: https://urn.nsk.hr/urn:nbn:hr:131:902405

Rights / Prava: Attribution-NonCommercial-NoDerivatives 4.0 International/ImenovanjeNekomercijalno-Bez prerada 4.0 međunarodna

Download date / Datum preuzimanja: 2023-04-26

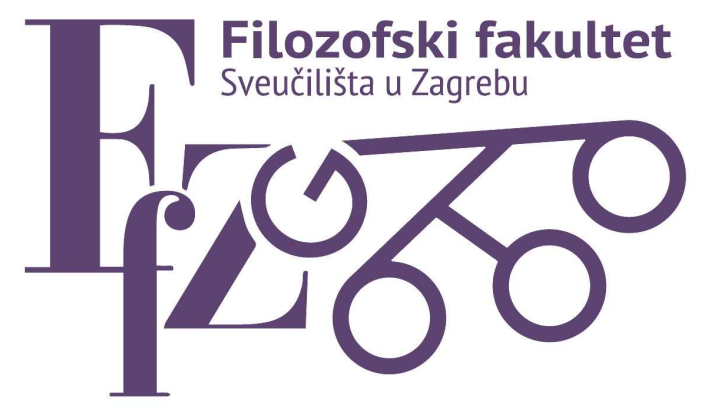

Repository / Repozitorij:

ODRAZ - open repository of the University of Zagreb

Faculty of Humanities and Social Sciences
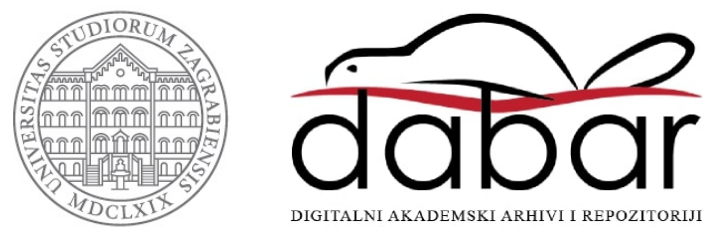


\section{Etika u arheologiji - od arheološkog iskopavanja do muzejskog izloška}

Chapter · December 2014

CITATIONS

0

2 authors:

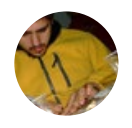

Petar Gabrić

University of Zagreb

5 PUBLICATIONS 0 CITATIONS

SEE PROFILE
READS

199

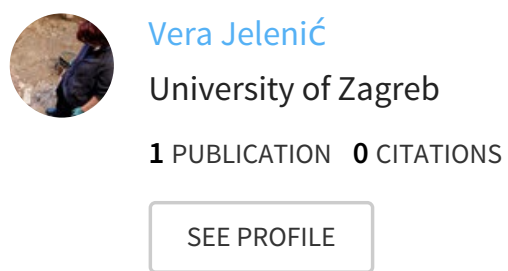




\section{Petar Gabrić}

pgabric@ffzg.hr

\section{Vera Jelenić}

vjelenic@ffzg.hr

Filozofski fakultet Sveučilišta u Zagrebu

\section{ETIKA U ARHEOLOGIJI - OD ARHEOLOŠKOG ISKOPAVANJA DO MUZEJSKOG IZLOŠKA}

Sažetak: Kulturna baština je jedan od najvažnijih aspekata suvremenog društva. Upravo je arheologija kao znanost bitan čimbenik koji iskopani arheološki nalaz analizom, interpretacijom i prezentacijom oblikuje u ono što će se u budućnosti zvati kulturnom baštinom. Medutim, na putu nalaza od iskopavanja do muzejskog predstavljanja arheolozi $i$ srodni stručnjaci nailaze na mnoge etičke dileme. Etika u arheologiji je tema koja se pojavila relativno kasno, tek u drugoj polovici 20. stoljeća, što je dijelom zbog političkih i povijesnih prilika, ali i novih dostignuća u znanstvenoj metodologiji nakon 1950-ih. Arheologija se bavi istraživanjem prošlosti, no nakon pitanja kako i kada je određena zajednica živjela, postavlja se pitanje zašto. Koja je svrha arheoloških istraživanja i poznavanja prošlosti? Naročito kada prošlost ima drugačije značenje za arheologa $i$ pukog čovjeka kao u slučaju Aboridžina i paleolitičkog špiljskog slikarstva u Arnhem Landu. To su osnovna moralna pitanja s kojima se susreće teorijska arheologija. U praksi arheolog nailazi na mnoga druga. S jedne strane, u pitanju je arheolog koji već samim činom iskopavanja uništava $i$ Zemljinu površinu i često nečije privatno vlasništvo. Nadalje, arheolog mora pokazati odgovornost pri postupanju s posthumnim ostacima čiji se dijelovi nakon analiza iz određenih razloga uništavaju. Treba imati na umu da su ti osteološki nalazi posmrtni ostaci nečijeg pretka. Slično ovome problemu predstavljaju i etnoarheološka istraživanja kojima je cilj proučavanje života postojećih zajednica kako bi se rekonstruirao život zajednica u daljoj prošlosti. Takva istraživanja ugrožavaju privatnost članova tih zajednica, a da kao takva gotovo nikada ne daju pouzdane i egzaktne rezultate. S druge strane, nisu samo arheolozi oni koji svojim lošim moralnim prosudbama mogu negativno utjecati na arheološku baštinu. Namjerno uništavanje kulturnih spomenika kao čin religijskog ekstremizma, upotreba arheologije 
u političke svrhe kao kod imena i zastave države Bivše Jugoslavenske Republike Makedonije, ali i muzejske zbirke temeljene na ukradenim nalazima poput zbirke British Museuma samo su dio suvremenih moralnih rasprava u okviru arheologije. Ovim radom obradit ćemo ovu kompleksnu interdisciplinarnu temu te pokušati ukazati na moguća rješenja navedenih etičkih problema u suvremenoj arheologiji.

Ključne riječi: arheološki nalaz, etnoarheološka istraživanja, teorijska arheologija, kulturna baština, etički problemi

\section{UVOD}

Kulturna baština jedan je od najvažnijih aspekata suvremenoga društva. Upravo je arheologija kao znanost bitan čimbenik koji iskopani arheološki nalaz analizom, interpretacijom i prezentacijom oblikuje u ono što će se u budućnosti zvati kulturnom baštinom. Međutim, na putu nalaza od iskopavanja do muzejskoga predstavljanja arheolozi i srodni stručnjaci nailaze na mnoge etičke dileme.

Etika $\mathrm{u}$ arheologiji jest tema koja se pojavila relativno kasno i to tek $\mathrm{u}$ drugoj polovici 20. stoljeća zbog političkih i povijesnih prilika, ali i novih dostignuća u znanstvenoj metodologiji nakon 1950-ih godina. Arheologija se bavi istraživanjem prošlosti. Nakon pitanja kako i kada je određena zajednica živjela, postavlja se pitanje zašto bi se arheološka istraživanja uopće trebala provoditi. Koja je svrha arheologije i poznavanja prošlosti kada prošlost ima drugačije značenje za arheologa i običnoga čovjeka kao u slučaju Aboridžina i paleolitičkoga špiljskog slikarstva u Arnhem Landu? To su osnovna moralna pitanja s kojima se susreće teorijska arheologija. $\mathrm{U}$ praksi arheolog nailazi i na mnoga druga pitanja. Najprije je u pitanju arheolog koji već samim iskopavanjem uništava i Zemljinu površinu i često nečije privatno vlasništvo. Nadalje, arheolog mora pokazati odgovornost pri postupanju s posthumnim ostacima čiji se dijelovi nakon analiza iz određenih razloga uništavaju. Treba imati na umu da su ti osteološki nalazi posmrtni ostaci nečijega pretka. Slično ovome problemu, predstavljaju i etnoarheološka istraživanja kojima je cilj proučavanje života postojećih zajednica da bi se rekonstruirao život zajednica u daljoj prošlosti. Takva istraživanja ugrožavaju privatnost članova tih zajednica, a da kao takva gotovo nikada ne daju pouzdane i egzaktne rezultate. S druge strane, nisu samo arheolozi oni koji svojim lošim moralnim prosudbama mogu negativno utjecati na arheološku baštinu. Namjerno uništavanje kulturnih spomenika kao čin religijskoga ekstremizma, upotreba arheologije u političke svrhe kao u imenu i za zastavu države bivše jugoslavenske 
Republike Makedonije, ali i muzejske zbirke utemeljene na ukradenim nalazima poput zbirke British Museuma samo su dio suvremenih moralnih rasprava u okviru arheologije.

Ovim radom obradit ćemo ovu kompleksnu interdisciplinarnu temu te pokušati ukazati na moguća rješenja navedenih etičkih problema $u$ suvremenoj arheologiji.

Rad smo podijelili u dva dijela. Prvi dio rada tiče se etike tijekom arheološkoga istraživanja. Bit će objašnjen odnos arheologije i mrtvih te odnos arheologa i mjesne zajednice. Drugi dio rada razjašnjava etiku nakon arheološkoga istraživanja pri čemu se najviše obrađuju vlasništvo, politizacija i uništavanje arheološke baštine.

\section{ETIKA TIJEKOM ARHEOLOŠKOGA ISTRAŽIVANJA}

Budući da se arheologija bavi rekonstrukcijom života prošlih zajednica, neizbježno je da se bavi i mrtvima. Prvi ljudi za koje se sigurno zna da su pokapali svoje mrtve bili su neandertalci (Homo sapiens neanderthalensis) koji su se pojavili u razdoblju koje nazivamo srednji paleolitik, odnosno srednje starije kameno doba, a koje se ugrubo datira od oko 300000 do 30000 godina prije današnjega vremena. Od neolitika, odnosno mlađega kamenog doba, govori se o nekropolama, grobljima u arheološkom smislu. Riječ nekropola dolazi iz starogrčkoga jezika kao složenica riječi vekpós

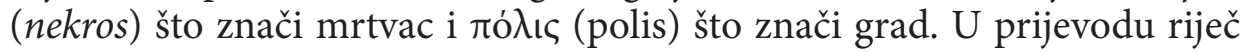
nekropola značila bi grad mrtvih. U arheologiji ostaci pokojnika u većini su slučajeva isključivo osteološki nalazi. U rijetkim se slučajevima očuva meko tkivo, na primjer kod posmrtnih ostataka očuvanih u tresetu, ledu te manja količina kod mumija. U suvremenoj arheologiji povezivanjem s prirodnim znanostima potpuna analiza posmrtnih ostataka postala je uobičajena arheološka praksa (u povoljnim financijskim uvjetima). Takva analiza uključuje osnovne postupke poput određivanja biološkoga profila pokojnika (spol, biološka starost, visina, moguće patološke promjene i slično), analize izotopa ugljika ${ }^{14} \mathrm{C}$ radi utvrđivanja kronološke starosti nalaza, analize stabilnih izotopa dušika ${ }^{14} \mathrm{~N} \mathrm{i}^{15} \mathrm{~N}$, ugljika ${ }^{12} \mathrm{C} \mathrm{i}^{13} \mathrm{C}$ te stroncija ${ }^{86} \mathrm{Sr}$ i ${ }^{87} \mathrm{Sr}$ radi određivanja prehrane, DNK analize i tako dalje (Renfrew et al., 2012).

U svrhu ovih analiza uzimaju se manji dijelovi kostiju, najčešće dugih, tako da su izlaganje pokojnika ovim analizama te sam čin iskopavanja pokojnika iz njegovoga groba izvori mnogih moralnih pitanja. Etička načela treba se držati svaka znanost koja se izravno bavi čovjekom. Tako je i s humanom osteoarheologijom. Najprije trebamo objasniti razloge moralnih pitanja, odnosno što je to u arheologiji mrtvih moralno upitno. Etika je kulturno i 
ideološki utemeljena, nije transcendentna i univerzalna (Tarlow, 2006) tako da ono što će u okviru arheologije za nekoga u Vatikanu biti neprihvatljivo, za nekoga u Iraku neće biti takvo. Prvi problem u arheologiji mrtvih može nastati u slučaju postojanja kulturne ili čak genetičke nasljedne zajednice koja se potencijalno ne bi složila $s$ istraživanjem nad nekim pokojnikom koji je s tom zajednicom povezan. Nasljedna zajednica može s pokojnikom biti kulturno povezana ako se radi o zajednici koja je kulturološki nastavak prošle zajednice koja se istražuje kao što je to slučaj s Vatikanom ili može biti genetička ako se radi o istom narodu koji je preživio na tom teritoriju kao što je to u Indijanaca i Aboridžina. No, kada je riječ o Europi, izuzetno se rijetko radi o genetičkim nasljednim zajednicama. Zašto bi neka kulturna nasljedna zajednica mogla neprimjerenim smatrati analizu posmrtnih ostataka? U prvom redu radi se o uznemiravanju zagrobnoga života, odnosno razlozi su religiozni. Eventualno postojanje zagrobnoga života može biti tema filozofskih rasprava, ali arheolozi bi trebali biti objektivni i pretpostaviti da analiza ostataka pokojnika ne predstavlja prijetnju miru u pokojnikovu eventualnom zagrobnom životu. Za arheologa je bilo kakav uzorak potencijalni izvor novih podataka.

Međutim, treba imati na umu da je većinsko svjetsko stanovništvo religiozno. Prema Globalnom indeksu religioznosti i ateizma objavljenom 2012. godine 59\% svjetskoga stanovništva jest religiozno (Global Index of Religiosity and Atheism, 2012). Tako se na primjer Rimokatolička crkva ne protivi nužno arheološkoj analizi posmrtnih ostataka, ali s druge strane zabranjuje obdukciju pape nakon njegove smrti. Budući da je od 236 preminulih papa za samo stotinjak poznato gdje im se nalazi grobnica, moguće je da jednoga dana neki arheolog naiđe na grob nekoga pape. Ako bi se utvrdilo da se u tom grobu zaista nalazi papa, bi li arheolog trebao slušati religiozne zahtjeve Rimokatoličke crkve ili bi trebao iscrpiti sve mogućnosti za znanstvenu analizu te time napraviti tip obdukcije? Ovdje se, naravno, postavlja i pitanje moralne opravdanosti ovakvih pravila. Budući da Vatikan nije član velikih međunarodnih organizacija poput Ujedinjenih naroda i Europske unije, ostaje uglavnom na njemu da oblikuje svoje zakone što je moralno prihvatljivije moguće.

U filmu The Mummyiz 1999. godine, koji je na hrvatski jezik preveden kao Mumija, likovi Rick O'Connell, Evelyn Carnahan i ostatak družine odlaze na kvaziarheološko iskopavanje u fiktivnu Hamunaptru, staroegipatski grad mrtvih. Pri dolasku u Hamunaptru zaustavljaju ih Medjai i upozoravaju ih na opasnosti koje bi mogle proizaći zbog iskopavanja u Hamunaptri. Istraživači ne poslušaju Medjaije te probude mumiju, svećenika Imhotepa koji dalje u filmu ubija istraživačku skupinu koja je otkrila njegov grob ne bi li ponovno poprimio potpuni ljudski oblik. Bez obzira ne to što se radi o 
fantastičnom filmu, praznovjerne skupine poput Medjaija postoje i danas, a boje se takozvanoga faraonovog prokletstva. Faraonovo prokletstvo, unatoč imenu, odnosi se na sve egipatske pokojnike, a posebice faraone. Često su ta prokletstva ispisana u grobnicama, a kažu da će onoga tko uznemiri pokojnika, dakle otvori mu grobnicu, zadesiti velika nesreća, bolest ili smrt. Određene skupine u Egiptu ne slažu se s iskopavanjima jer strahuju da bi se prokletstvo moglo proširiti na cijeli Egipat kao što je to prikazano u filmu Mumija. Ipak su u Egiptu u arheološkom kontekstu glasnije radikalne islamske skupine koje cijelu egipatsku civilizaciju smatraju nepoćudnom jer nije bila islamska pa iz toga razloga ne podržavaju veličanje egipatske civilizacije, ali turizam ovdje igra veliku ulogu u očuvanju kulturne baštine. O radikalnim islamistima bit će riječi i nešto kasnije. Iz ovoga primjera očito je da u određenim situacijama može doći do prijepora između arheologa i mjesne zajednice. Na univerzalnoj razini ne postoje nikakvi etički kodeksi kojih bi se svaki arheolog trebao pridržavati. Zato se možemo pozivati tek na nekakve dogovore i sporazume sklopljene na nekakvim kongresima. Tako na primjer treći članak često citiranoga Vermillionskog dogovora o ljudskim ostacima (Vermillion Accord on Human Remains) iz 1989. godine nalaže da pri arheološkim istraživanjima treba poštovati želje mjesne zajednice te, ukoliko postoje, potomaka i zaštitnika pronađenih pokojnika. Međutim, taj članak pomalo je kontroverzan. Ako ga se poštuje, praktički se omogućuje mjesnoj zajednici, koja ne mora imati nikakvu praksu ili znanja o tretiranju ljudskih ostataka, da zaustavi bilo kakva arheološka istraživanja. Budući da ljudske zajednice već 200000 godina pokapaju svoje mrtve, veliki bi dio arheologije potencijalno stao.

Jedan od najpoznatijih sporova između arheologa i mjesne zajednice trajao je od 1996. do 2005. godine u SAD-u. Arheolozi su bili pronašli kostur za koji se datiranjem ustanovilo da je star oko 9300 godina te bi se time moglo dati mnogo odgovora na pitanje početka naseljavanja Sjeverne Amerike. Međutim, lokalni Indijanci nisu dopustili analizu tvrdeći da je on njihov predak i pozivajući se na Odluku o zaštiti i vraćanju indijanskih grobova (Native American Graves Protection and Repatriation $A c t)$ iz 1990. godine. Ta odluka nalaže da svi grobovi Indijanaca zapravo pripadaju Indijancima ako se može dokazati veza između groba i postojeće zajednice. Tako su nakon 1990. godine mnogi ostaci pokojnika morali biti vraćeni zajednicama. Kennewick Man bio je previše važan nalaz da bi se samo tako mogao prepustiti Indijancima, tim više što bi se teško mogla dokazati genetička povezanost današnjih Indijanaca toga područja i pokojnika. Nakon devet godina sudskoga spora i milijuna potrošenih dolara odlučeno je da arheolozi imaju pravo na Kennewick Mana zato što se ne može ustanoviti nikakva genetička povezanost između njega i 
lokalnih Indijanaca (Thomas, 2001). Slični su događaji obilježili i povijest arheologije u Australiji u kojoj su masovno bili iskopavani Aboridžini i to ne samo oni stari nekoliko tisuća i desetaka tisuća godina već i recentni grobovi. Danas je uobičajeno da se pokojnici vraćaju Aboridžinima kako bi ih oni mogli ponovno pokopati, a vraćaju se čak i ostaci stari nekoliko desetaka tisuća godina koji predstavljaju veliku važnost za istraživanje ranih faza pojave Homo sapiensa sapiensa u Australiji. Australija i Sjeverna Amerika predstavljaju različitu situaciju u odnosu na Europu gdje je, kao što je već rečeno, rijedak slučaj genetičke nasljedne zajednice koji je na navedena dva kontinenta očit.

Doduše, zajednice ne predstavljaju u arheologiji samo izvor etičkih pitanja koja bi uvelike mogla utjecati na tijek arheološkoga istraživanja. Mjesne zajednice također su zainteresirane za rezultate arheoloških istraživanja. Tako se na primjer mogu provoditi istraživanja drevne DNK (ancient DNA) ako za to postoje financijske mogućnosti kao što je to $\mathrm{u}$ istraživanju turskoga lokaliteta Çatalhöyüka ${ }^{1}$ kako bi se ustanovila genetička povezanost živih zajednica i arheoloških zajednica. Çatalhöyük može služiti i kao školski primjer objašnjavanja odnosa arheologa i mjesne zajednice. Mještani su tijekom istraživanja na Çatalhöyüku bili uključeni u osnovne poslove tijekom iskopavanja, a velika istraživanja su im donijela izgradnju novoga vodoopskrbnog sustava, nove škole i knjižnice. Što se pak teme ovoga rada tiče, važno je istaknuti da su mještani bili i izravno uključeni u istraživanje. Nakon iskopavanja sudjelovali su u raspravama o interpretaciji nalaza i cijeloga nalazišta zato što su mogli pridonijeti svojim znanjima o specifičnim događajima na tom području koji utječu na njihov svakodnevni život poput teškoća zimskoga života, utjecaja vjetrova, vrsta gline koja bi se mogla koristiti za izradu peći i tako dalje (Hodder, 2002).

Dosad smo obradili odnos arheologa i mjesne zajednice. Pri tome smo se posebno osvrnuli na one mjesne zajednice koje znaju biti glasne kada su u pitanju pokojnici. Budući da je riječ o pokojnicima, bilo bi možda bolje okrenuti se željama pokojnika, a ne željama mjesne zajednice o pokojniku. Danas ljudi imaju pravo odlučiti što će biti s njihovim tijelima nakon smrti. Hoće li biti kremirani ili pokopani u lijesu? Za pokojnikove želje danas vrijedi koncept društvenoga ugovora. To znači da će se te želje ispuniti, doduše samo u slučaju da je želja realna. Ne možemo naravno tražiti da se naš pepeo pospe po Marsu ili da nas se pokopa na Mount Everestu. Također osoba može odlučiti hoće li predati svoje tijelo za pomoć pri liječenju drugih osoba ili će predati tijelo za znanost. Tako danas u Hrvatskoj postoji princip donorske kartice i općenito doniranja organa u

1 Çatalhöyük je turski protoneolitički lokalitet koji je datiran u razdoblje između oko 7400. i 6200. godine prije nove ere. (Hodder u: Near Estearn Archaeology br. 65, 2002.) 
svrhe transplantacije koji je uređen Zakonom o uzimanju i presađivanju dijelova ljudskog tijela u svrhu liječenja. Pri tome u Hrvatskoj vrijedi načelo pretpostavljenoga pristanka, odnosno ili je osoba ispunila donorsku karticu kojom potvrđuje da je voljna dati organe nakon smrti ili se nije tijekom života izjasnila o doniranju organa pa obitelj treba donijeti odluku. Postoji izjava o nedarivanju kojom osoba potvrđuje da ne želi donirati svoje organe nakon smrti. Moguće je također i donirati svoje tijelo znanosti, na primjer Zavodu za anatomiju Medicinskoga fakulteta Sveučilišta u Zagrebu. U te svrhe također postoji donorska kartica kojom se potvrđuje pristanak da se tijelo nakon smrti može analizirati u znanstvene svrhe. U prošlosti ovakvi koncepti nisu postojali ili nisu bili uređeni zakonima, odnosno pravilnicima. Prema tome, odluka o sudbini tijela nakon smrti jest nešto što se $u$ suvremenom društvu poštuje tako da se može pretpostaviti da bi arheolog pri iskopavanju groba trebao poštovati želje pokojnika. Tako nalaže i drugi članak već spomenutoga Vermillionskog dogovora o ljudskim ostacima u kojem stoji da se želje pokojnika u vezi pokopa, ukoliko su razumne, moraju poštovati. Je li moguće i kako za grobove stare i po nekoliko tisuća godina, pa čak i stotina tisuća godina kao u neandertalaca, znati koja je bila pokojnikova želja? Određeni oblici pokopa na koje arheolozi nailaze poput čuvanja mumija u egipatskim piramidama, prevlačenja pokojnika plemenitim metalima (Goffer, 2007) ili žadom te polaganja pokojnika $\mathrm{u}$ velike grobnice s bogatim grobnim prilozima ukazuju na to da je cilj takvih pokapanja očuvanje pokojnika koliko god je to moguće. U Egipćana već smo posebno spomenuli tzv. faraonovo prokletstvo. Znači li to da se takvi grobovi ne bi trebali iskopavati i da arheolozi zapravo svakodnevno oduzimaju pokojnicima ljudska prava?

Ovdje se postavlja i problem grobnih priloga koji imaju simboličnu funkciju praćenja pokojnika u zagrobni život. Na primjer u halštatskom ${ }^{2}$ kneževskom grobu iz Hochdorfa pronađen je uz pokojnika, između ostaloga, i kotao obujma 400 litara s tragovima meda koji upućuju na to da je u njemu bila medovina (Potrebica, 2013). Odvajanje pokojnika od kotla možda bi za njega značilo to da će i u zagrobnom životu biti udaljen od medovine te je neće moći piti. Poštovanje želja pokojnika danas se temelji na konceptu takozvanoga društvenog ugovora koji bi se trebao poštovati (Scarre, 2006). Međutim, društveni ugovori u arheologiji nisu praktični jer ne možemo znati što je knez iz Hochdorfa točno htio i bi li donirao svoje tijelo znanosti da je znao da će netko možda u 20. stoljeću iskopati njegov grob. Društveni ugovor gotovo je nemoguće rekonstruirati u razdobljima poput srednjega

2 Halštat je naziv za starije željezno doba Europe koje traje od otprilike 9. do 5. stoljeća prije nove ere. Dobilo je ime po željeznodobnom groblju i rudniku soli u Hallstattu u Austriji. 
paleolitika ${ }^{3}$ kada u Europi borave neandertalci, prvi ljudi (članovi roda Homo) za koje se sigurno zna da su pokapali svoje mrtve (Janković et al., 2009). Nadalje, u zooarheologiji onda nikako ne može vrijediti koncept društvenoga ugovora. Doduše, danas se koncept društvenoga ugovora u određenim slučajevima može raskinuti, na primjer kada nadležni sud dopusti ekshumaciju ako za nju postoje valjani razlozi, no arheolozi ne moraju tražiti posebne dozvole za iskopavanje pokojnika. U ovom kontekstu postavlja se pitanje smisla arheoloških istraživanja koji bi opravdao vađenje pokojnika iz njegovoga groba i prema nekima njegovo uznemiravanje. Na primjer, u medicini su istraživanja opravdana jer doprinose boljitku društva u smislu očuvanja zdravlja. Možemo reći da arheologija doprinosi poznavanju prošlosti, ali to samo po sebi u većini slučajeva nije nešto što izravno doprinosi životu ljudi. Rezultati arheoloških istraživanja mogu se koristiti u političke svrhe, ali to može ovisno o kontekstu biti i loše i dobro kao što ćemo vidjeti dalje u radu. S druge strane, zašto bi neki pokojnik bio miran i mjesna zajednica zadovoljna samo dok njegovi ostaci ne dospiju u ruke arheologa? Nakon pokopa u zemlju s vremenom se razgrađuje meko tkivo, a u slučajevima kiselih tala, kao što je slučaj s istočnom Engleskom, u potpunosti se razgrađuju i kosti pa od pokojnika ostane samo silueta u tlu. Takvi se procesi ne smatraju narušavanjem želja pokojnika iako je on možda htio ostati vječno pokopan u svojem grobu. Nadalje, kršenje društvenoga ugovora nije samo problem arheologa. U 18. stoljeću u Parizu svi gradski grobovi premješteni su u pariške katakombe jer za njih u gradu više nije bilo mjesta. Tako su pokojnici, koji su bili pokopani oko katedrale Notre-Dame, bili premješteni u pariško podzemlje, a vjerojatno ne bi bili nikako zadovoljni da su za života znali da će se njihovim tijelom dogoditi ovakva drastična promjena lokacije. Zbog ovakvih primjera arheolozi poput Jonesa i Harrisa smatraju da društveni ugovor ne vrijedi za pokojnike u arheološkom kontekstu (Tarlow, 2006).

Osim pitanja pokojnikovih želja, postavlja se i pitanje privatnosti. Privatnost nismo u početku pripreme ovog rada razmatrali kao problem $\mathrm{u}$ arheologiji, ali nakon određenih događaja ovoga tjedna ipak smo uvrstili i tu temu u izlaganje. Ovdje je ponajprije pitanje izlaganja pokojnika u muzejima i zbirkama. Tako se na primjer u Arheološkom muzeju u Zagrebu u posebnoj sobi čuva tzv. zagrebačka mumija. Vrlo je neizgledno da bi ta Egipćanka s obzirom na njezina pretpostavljena vjerovanja ikad pristala na ponajprije vađenje iz grobnice, a kamoli da je se izlaže u vitrini da je cijeli svijet može vidjeti. Nadalje, suvremenim analizama dobije se kompletan biološki profil pokojnika kao što smo već i rekli. Saznavanje svih patoloških

3 Srednji paleolitik ili srednje starije kameno doba ugrubo se kronološki postavlja u razdoblje između oko 300000 i 30000 godina prije sadašnjosti. 
promjena i mogućih razloga zbog kojih su one nastale te otkrivanje da je neka žena rodila izvanbračno dijete stvari su koje uobičajena osoba ne bi htjela podijeliti s ostatkom svijeta, a arheolozi nude takve informacije na pladnju. Prije tri dana Europski sud u Luksemburgu odlučio je da građani imaju pravo naložiti Googleu da se njihovi podaci za koje ne žele da stoje na internetu izbrišu iz tražilice. Zasigurno ima mnogo arheoloških ličnosti koje bi htjele da određeni podaci nisu dostupni svijetu, ali tko će njih zagovarati? Njih sigurno neće zagovarati arheolozi jer je u našem interesu da su takvi podaci dostupni. Ako onda pretpostavimo da arheolozi smiju iskopavati grobove i analizirati ostatke pokojnika, a tako bismo zasigurno i voljeli, trebamo istaknuti osnovna etička pravila pri tretiranju ostataka pokojnika. U već spomenutom Vermillionskom dogovoru o ljudskim ostacima prvi članak nalaže da se poštovanje mora iskazati prema ostacima svih pokojnika neovisno o porijeklu, rasi, vjeroispovijesti, etničkoj pripadnosti ili tradiciji. No, Vermillionski dogovor ponovno je ostao nedorečen pa nije baš u potpunosti jasno što poštovanje konkretno u arheologiji znači. Poštovanje je apstraktan pojam koji je Vladimir Anić definirao kao osjećaj da tko ili što posjeduje istaknute i poželjne odlike, da ima zasluge (Anić, 1991). Što bi to značilo u arheološkoj praksi? Minimalno iskazivanje poštovanja prema ostacima pokojnika značilo bi otprilike to da se pokojnicima ne daju nadimci ili da se kosti ne koriste za zbijanje šala kao što se među studentima voli koristiti nadlaktica i natkoljenica $\mathrm{u}$ imitaciji primitivnoga oružja ili se pak pokušava ugurati lubanju da sjedne u zdjelicu. Krajnji oblik poštovanja bio bi ponovni ukop pokojnika nakon istraživanja što se, kao što smo već rekli, prakticira u Australiji i u SAD-u. Iako arheolozi u pravilu pokazuju potrebno poštovanje prema pokojnicima, postoje slučajevi u povijesti arheologije koji pokazuju kršenje i minimalnih načela pokazivanja poštovanja.

Tako su na primjer poznati nalaz ženskoga kneževskog groba, takozvane kneginje iz Vixa, u početnim interpretacijama neki nazivali željeznodobnim svećenikom transvestitom. Razlog su bili slabo očuvani osteološki ostaci pokojnice koji tada nisu sa sigurnošću mogli pokazati radi li se o muškarcu ili ženi, a velika količina pronađenoga nakita sugerirala je da se radi o ženskom grobu, no nekim arheolozima je tada bilo teško zamisliti da bi žena mogla biti pokopana u tako bogatom grobu. Danas se zna da je riječ o ženi, a nikako o transvestitu (Potrebica, 2013).

Nadalje, povijest arheologije ne bilježi samo ovakvo banalnije nepoštivanje pokojnika. Poznato otkriće Tutankamonove grobnice 1924. godine učinilo je Howarda Cartera jednim od najpoznatijih ličnosti egiptologije. No, manje je poznato da se upravo Howard Carter s velikim nepoštovanjem i neoprezom odnosio prema posmrtnim ostacima 
Tutankamona. Prve rendgenske snime mumije iz 1968. godine pokazale su da su pod vodstvom Howarda Cartera odlomljeni i gornji i donji udovi da bi se došlo do vrijednog nakita, ali je bila odlomljena i glava da bi se došlo do maske. Također je uspostavljeno da nedostaju Tutankamonovo desno uho i penis za koje se prema fotografijama Howarda Cartera zna da su bili sačuvani na mumiji. U trenucima velikih egiptoloških otkrića bilo je popularno uzeti dio mumije te ga smrviti, staviti u napitak u nadi boljega zdravlja i slično, tako da je moguće da je takva sudbina zadesila faraonov penis i njegovo desno uho (Harrison et al., 1972).

Problem arheologije mrtvih jest problem koji bi se trebao sagledavati od slučaja do slučaja. Nije jednako radili se o Europi ili Australiji zbog postojanja genetičkih nasljednih zajednica. $U$ tom smislu nije moguće uspostaviti univerzalni etički kodeks. Međutim, za osnovna bi se etička pravila kodeks trebao poštovati. Ponašanje Carterovoga tima s Tutankamonom nije samo slučaj nepoštivanja pokojnika, nego i uništavanja arheoloških nalaza. Doduše treba napomenuti da se ovakvi slučajevi vežu uglavnom za 20. stoljeće i ranija razdoblja arheologije, ali svejedno je potrebno bilo kakvim pravilnikom naglasiti potrebu za oprezom i poštovanjem pri tretiranju ostataka pokojnika.

\section{ETIKA NAKON ARHEOLOŠKOG ISTRAŽIVANJA}

Vlasništvo arheološke baštine vjerojatno predstavlja najveći problem u arheološkoj etici nakon arheoloških istraživanja. Od poznatijih primjera su metope s Partenona s atenske akropole koje se danas čuvaju u British Museumu u Londonu te Nefertitina bista stara oko 3300 godina koja se čuva u Neues Museumu u Berlinu. Iz ovih dvaju primjera pretpostavljamo da je jasno da postoje slučajevi u kojima je vlasništvo arheološke baštine upitno. Ovo su samo neki od poznatijih slučajeva. Postoje mnogi drugi slučajevi, čak i u Hrvatskoj. Oni su posljedica iskopavanja stranih arheologa u Grčkoj, Egiptu, Turskoj i tako dalje koji su onda, često ilegalno, prebacivali iskopine preko granice. Tako je u slučaju grčkih metopa glasoviti lord Elgin, škotski diplomat, došao u Grčku i uklonio neke blokove mramora s Partenona uz dopuštenje osmanske vlasti koja je u to vrijeme vladala Grčkom. Lord Elgin taj je mramor kasnije prodao British Museumu u Londonu. Danas Grci smatraju da bi im se ti mramori s prikazom metopa trebali vratiti te vrše pritisak na Ujedinjeno Kraljevstvo koliko god je to moguće. No, često je riječ i o običnim ljudima koji metalnim detektorima i sličnim napravama traže dragocjene predmete koje onda preprodaju u velike muzeje. Istina je da bi British Museum u Londonu i Metropolitan Museum u New Yorku ostali s vrlo slabim postavom kada bi odlučili vratiti ukradenu 
baštinu. Njima naravno nije u interesu vratiti baštinu zemljama kojima ta baština pripada, naročito u slučaju ovih dvaju muzeja koji su praktički postali simbol gradova u kojima se nalaze. Međutim, nije li ispravno da se materijal s atenske akropole vrati Grčkoj jer ne samo da Grčka traži svoju arheološku baštinu natrag nego joj ona i teritorijalno i kulturološki pripada? U ovakvim situacijama Grčkoj jedino preostaje povlačiti ovakve slučajeve po sudovima i plaćati vrtoglave sudske troškove ne bi li dobila natrag svoju baštinu. Ovdje se više radi o moralnom osuđivanju, nego o stvarnim pitanjima jer se uglavnom stvari logički slažu. Ako bi nama netko nešto ukrao, očekivali bismo da nam se ukradeno vrati te da se počinitelj kazni. No, ovo nije samo pitanje očuvanja nacionalne kulturne baštine. I u čisto arheološkom smislu ovakve radnje predstavljaju velik problem jer taj materijal nije moguće interpretirati zato što ne postoji arheološki kontekst. Kao što smo već na početku rada rekli, arheolozi interpretiraju sve nalaze zajedno tako da je teško samo tako uvrstiti Nefertitinu bistu u kontekst svih nalaza iz egipatske Amarne, naročito teško kada neprofesionalni ljudi vrše ilegalna iskopavanja i preprodaju pronađeni materijal.

Međutim, nije pitanje vlasništva arheološke baštine ograničeno samo na muzeje i slične institucije. Pitanje vlasništva neki postavljaju odmah nakon pronalaska arheološkoga nalaza. Tako neki zastupaju mišljenje da se osoba, koja pronađe neki arheološki nalaz u netaknutom kontekstu, smije smatrati njegovim vlasnikom dok drugi zastupaju mišljenje da je ipak kultura (narod, država) ta koja ima pravo na pronađenu baštinu. U nekim slučajevima povezanost naroda $s$ arheološkim artefaktima više je nego jasna pa se narod, odnosno država, čini najboljim vlasnikom arheološke baštine. Najbolji je primjer za to Meksiko koji traži svoje pravo na artefakte iz pretkolumbovskoga doba. Riječ je o multikulturalnoj državi u kojoj danas žive potomci domorodačkoga stanovništva i potomci konkvistadora. Konkvistadori su u 16. stoljeću kao dio španjolske ekspedicije u dotada neotkrivenoj Srednjoj Americi zauzeli Meksiko.

Koncept naslijeđa u pitanju vlasništva nad nekom imovinom, u ovom slučaju nad arheološkim nalazom, primjenjuje se samo u slučaju ako je sačuvana posljednja oporučna želja vlasnika nalaza. Prilikom iskopavanja arheolozi nailaze na artefakte koji su u prošlosti bili vlasništvo neke zajednice. $U$ tom slučaju mi ne možemo nikako znati kakva je bila posljednja želja prvotnoga vlasnika tako da samo možemo pretpostaviti da su htjeli da ipak određeni vrijedni predmet ili predmet koji je njima bio od posebnoga značenja ostane unutar obitelji, među potomcima. Budući da se radi o dalekoj prošlosti, teško je odrediti tko je od cijele obitelji i rodbine bio vlasnik određenoga predmeta. Isto tako, klanovi i određene religijske zajednice prestali su postojati. Stoga, možemo opet samo pretpostaviti 
da su možda htjeli da se njihova imovina u budućnosti nađe u sigurnim rukama vlasnika koji će omogućiti da ona bude dostupna široj javnosti. Problem, koji se provlači ovim konceptom, jest konstantna promjena kulture. Na primjeru Grčke može se zaključiti da moderna Grčka nema nikakve povezanosti s antičkom Grčkom u smislu religije i kulturnih običaja. Budući da kulture nisu identične, koncept naslijeđa ne može se primijeniti.

Drugi problem jest tretiranje izgubljene i napuštene imovine. U slučaju napuštene imovine prvotni vlasnik koji je napustio predmet, nema više pravo tražiti pravo na taj predmet i time nitko to više ne može naslijediti od te osobe. Kada druga osoba slučajno pronađe taj predmet, može ga prisvojiti. To ima veze s namjerom prvotnoga vlasnika koji je očito planirao napustiti imovinu. S druge strane, nije se planiralo da se izgubljena imovina izgubi. U slučaju da neka osoba pronađe neki izgubljeni predmet smije ga prisvojiti jedino ako se ne zna tko je prvotni vlasnik predmeta zato što vlasnici nikada ne gube pravo na taj predmet. No, ponovno bi pronalazač nekoga artefakta trebao prijaviti pronalazak nadležnoj instituciji da bi se on mogao znanstveno obraditi. Međutim, nekada se dogodi da arheolozi, kao i ostali, pogrešno prisvoje određene artefakte koji nisu napušteni. To se najbolje vidi u primjeru indijanskoga plemena Zuñi iz američke države Novi Meksiko. Članovi toga plemena svake godine izrađuju po dvije religijske statue bogova ratnika za koje oni vjeruju da će im pružati zaštitu i sigurnost. Ti skulptori izrađuju statue s namjerom da one postanu vlasništvo Zuñi plemena. Pred kraj godine, članovi plemena odnose statue na skriveno mjesto s namjerom da one istrunu i da se tako povežu sa zemljom i ostalim elementima. Taj čin predstavlja dio njihova vjerovanja da će ti bogovi ratnici ojačati zemlju. S vremenom ljudi su pronalazili te religijske statue i iskorištavali njihovu ekskluzivnost tako da su ih davali muzejima diljem Amerike ili privatnim kolekcijama (Young, 2006). To je pogrešno i očiti je prikaz nepoštivanja imovine plemena koji nisu napustili svoje statue bezrazložno, već s opravdanim razlogom - zbog svojega vjerovanja.

Do ovoga dijela u radu su obrađena etička pitanja i načela koja se tiču arheologa i ostalih istraživača tijekom arheoloških istraživanja. Međutim, u kontekstu arheologije i obični bi se ljudi trebali držati određenih etičkih pravila. Najraširenija etički upitna uporaba arheologije i kulturne baštine jest ona u političke svrhe. Takva uporaba arheologije može biti i pozitivna i negativna. Pozitivna je na primjer uporaba u svrhe oblikovanja nacionalnoga identiteta kao što je vučedolska golubica ${ }^{4}$ simbol Vukovara,

4 Iako je u hrvatskoj javnosti već uvriježeno da se radi o golubici, to je manje vjerojatno. Dr. sc. Aleksandar Durman predlaže da se radi o jarebici. (Durman, 2006.) 
odnosno Hrvatske, ili pak ime razrušene prijestolnice Kraljevstva Zimbabve koje je poslužilo za imenovanje države u slučaju Zimbabvea. U povijesti su ipak poznatiji primjeri korištenja arheologije u negativne svrhe. Jedan je od najpoznatijih primjera sukob Republike Makedonije ${ }^{5}$ i Grčke oko imena prve države. BJR Makedonija preuzela je ime današnje grčke regije Makedonije koja ima veliku važnost u svjetskoj povijesti, ponajprije zbog Aleksandra Velikog Makedonskog. Nakon što se Socijalistička Federativna Republika Jugoslavija raspala na više država, izbila je velika kriza između Grčke i Makedonije. To je razumljivo s grčke strane. Da sukob bude veći, BJR Makedonija je kao nacionalni simbol preuzela zvijezdu koja se nalazi na zlatnoj kutiji koja je pronađena u grobnici iz 4. stoljeća prije nove ere u Vergini - grčkom naselju koje se čak ne nalazi ni na granici Grčke i BJR Makedonije. Za tu se zlatnu kutiju smatra da je pripadala ili Filipu II. Makedonskom, ocu Aleksandra Velikoga, ili Filipu III., Aleksandrovu polubratu. Spomenuta zvijezda i dan-danas nalazi se na zastavi BJR Makedonije (Renfrew et al., 2012). Ako odemo malo dalje u prošlost u 19. i 20. stoljeće, vidimo da su arheologiju koristili neki učenjaci i političari u pokušajima dokazivanje rasne nadmoći (Renfrew et al., 2012). Rasizam $\mathrm{u}$ arheologiji jest tema koja je i dalje aktualna zbog novih otkrića koja upućuju na to da su neki od najranijih holocenskih populacija u Europi bili tamnije puti (Olalde, 2014).

Gore navedeni primjeri, koliko god bili u nekim slučajevima moralno neprihvatljivi, ipak nisu destruktivni kao oni koje ćemo tek navesti. Kulturno naslijeđe često se u povijesti nalazilo na meti različitih zlonamjernih skupina tijekom ratnih vremena što vidimo i danas na području sjeverne Afrike i Bliskoga istoka. Nisu svi primjeri uništavanja kulturnoga naslijeđa vezani za rat i sukobe. Od srednjega vijeka nadalje Vatikan je sustavno antičkim skulpturama na mjestu penisa dodavao smokvine listove jer golotinja u rimokatoličanstvu smatra nečim neukusnim i nečim čega bi se osoba trebala sramiti. Ta je tradicija preuzeta iz Biblije u kojoj Adam i Eva, prvi ljudi na Zemlji prema kršćanskom mitu o postanku svijeta, pokrivaju smokvinim listovima svoju golotinju. Ipak je određen dio smokvinih listova do danas odstranjen, ali se na nekim skulpturama oni mogu i dalje vidjeti. Bez obzira na naše osobno mišljenje o primjenjivanju ove tehnike prikrivanja genitalija, u arheologiji su općenito ovakvi postupci svakako nedopustivi. Zamislite samo da preko falusa na prikazu itifaličnoga čovjeka u špilji Lascauxu, slici staroj 17300 godina, netko naslika smokvin list. $\mathrm{S}$ druge strane, postoje mnogo destruktivniji primjeri. Jedna od najvećih

5 Službeni naziv države je prema Ustavu te države Republika Makedonija, no u Ujedinjenim se narodima navodi kao Bivša Jugoslavenska Republika Makedonija zbog spora s Grčkom. Zbog tih razloga u daljnjem tekstu ćemo državu navoditi kao Bivšu Jugoslavensku Republiku Makedoniju, odnosno kraticom BJR Makedonija. 
katastrofa u povijesti uništavanja nekoga oblika kulturnoga naslijeđa jest talibansko uništavanje Bamiyanskih Buda u Afganistanu. U ožujku 2001. godine dvije monumentalne skulpture Buda, jedna visine 53 metra, druga 36 metara, uništene su eksplozivima jer nisu odgovarale islamskoj slici Afganistana zato što su predstavljale budističke spomenike. Talibani su uništili i neke artefakte iz Afganistanskoga nacionalnog muzeja u Kabulu (Renfrew et al., 2012). Za ovakve postupke religijskoga ekstremizma ne očekuje se da bi trebala postojati etička pravila, ali opet u ovakvim situacijama treba očekivati pravovremenu reakciju Ujedinjenih naroda, odnosno UNESCO-a.

\section{ZAKLJUČAK}

Kao što smo pokazali, arheologija je etički kompleksna disciplina. Tim je više kompleksna zato što ima više faza u svojem istraživanju, a sama po sebi nema neku određenu funkciju u društvu osim čisto znanstvene. Ovaj rad i neke njegove teze uglavnom samo temeljili na našim razmišljanjima zato što $\mathrm{u}$ arheologiji i dalje nije uspostavljen strogi univerzalni etički kodeks kojega bi se svi arheolozi trebali držati. To je vjerojatno najveći problem $\mathrm{u}$ arheološkoj etici. U medicini, na primjer, postoji Hipokratova zakletva koja čini temelje medicinske etike. Arheološka zakletva još nije na vidiku. $S$ druge strane, primjeri etičkih problema koje smo spomenuli u ovome radu, samo su mali dio svih etički upitnih događaja u povijesti arheologije. Iako etika sama po sebi nije egzaktna disciplina i često je najbolje posvetiti se posebno svakom problemu umjesto da se uspostavi univerzalna etika koja ne pita previše pojedince, dobro bi bilo donijeti barem osnovna etička pravila kojih bi se svi arheolozi morali pridržavati bez obzira na to jesu li sudjelovali na kongresu tijekom kojega je taj etički prijedlog donesen i bez obzira na to iz koje su države. Veliko je pitanje zašto takav osnovni vrijedeći kodeks već nije uspostavljen. 


\section{Literatura:}

Anić, Vladimir (1991) Rječnik hrvatskoga jezika. Zagreb: Novi liber.

Durman, Aleksandar (2006) Simbol boga i kralja: Prvi europski vladari. Zagreb: Galerija Klovićevi dvori.

Goffer, Zvi (2007) Archaeological Chemistry. Hoboken: John Wiley \& Sons, Inc.

Harrison, R. G.; Abdalla (1972) „The Remains of Tutankhamun“. Antiquity 46: 8-14.

Hoder, Ian (2002) „Ethics and Archaeology: The Attempt at Çatalhöyük“. Near Eastern Archaeology 65: 174-181.

Janković, Ivor; Karavanić, Ivor (2009) Osvit čovječanstva. Početci našega biološkog i kulturnog razvoja. Zagreb: Školska knjiga.

Olalde, Iñigo (2014) „Derived immune and ancestral pigmentation alleles in a 7000-year-old Mesolithic Europe“. Nature 507: 225-228.

Potrebica, Hrvoje (2013) Kneževi željeznoga doba. Zagreb: Meridijani.

Renfrew, Colin; Bahn, Paul (2012) Archaeology. Theories, Methods and Practice. London: Thames \& Hudson Ltd.

Scarre, Geoffrey (2006) „Can archaeology harm the dead“ u: Scarre, Chris; Scarre Geoffrey (ur.) The Ethics of Archaeology. Philosophical Perspectives on Archaeological Practice. New York: Cambridge University Press. Str. 181-199.

Tarlow, Sarah (2006) "Archaeological ethics and the people of the past" u: Scarre, Chris; Scarre, Geoffrey (ur.) The Ethics of Archaeology. Philosophical Perspectives on Archaeological Practice. New York: Cambridge University Press. Str. 199-219.

Thomas, David Hurst (2001) Skull Wars: Kennewick Man, Archaeology, and the Battle for Native American Identity. New York: Basic Books.

Young, James (2006) „Cultures and the ownership of archaeological finds“ u: Scarre, Chris; Scarre, Geoffrey (ur.) The Ethics of Archaeology. Philosophical Perspectives on Archaeological Practice. New York: Cambridge University Press. Str. 15-32.

Global Index of Religiosity and Atheism, 2012. 